\title{
Determinants of Economic Growth in Indonesia: A Dynamic Panel Model
}

\author{
Agus Tri BASUKI ${ }^{1}$, Yunastiti PURWANINGSIH ${ }^{2}$, Albertus Maqnus SOESILO ${ }^{3}$, Mulyanto MULYANTO ${ }^{4}$
}

Received: August 01, 2020 Revised: September 20, 2020 Accepted: October 05, 2020

\begin{abstract}
This study aims to analyze the effect of public spending, macroeconomic variables, and BPK opinion on economic growth. This study is motivated by the inequality of fiscal policy effectiveness between regions in Indonesia in influencing the economic growth of different regions, the ability of local governments to attract foreign investors, and the transparency of regional financial management in designing development programs to encourage regional economic growth. The analytical tool in this study is a dynamic panel regression model with data from 2008 to 2017. The results of this study show that, in the short term, the population affects regional economic growth, while in the long term, the economic growth is affected by the number of people, the poor, General Allocation Fund, health budget, foreign investment and BPK opinion. The findings of this study are that in the long term the General Allocation Fund becomes an obstacle to economic growth, this is because the general allocation funds is widely used to cover the lack of funds for routine regional activities, thereby reducing activities for development programs. Another research finding is that fiscal policies carried out by local governments make a small and ineffective contribution to promoting economic growth.
\end{abstract}

Keywords: Dynamic Panels, Economic Growth, Fiscal Policy, Public Spending

JEL Classification Code: C61, E62, F34, O23

\section{Introduction}

The weaknesses of domestic economy are evident from the unresolved issues of poverty, social inequalities, inequality among regions, and environmental degradation. They are caused by excessive exploitation of natural resources, food, energy, financial and technological dependence. The state is

${ }^{1}$ First Author and Corresponding Author. [1] Ph.D. Student, Economics and Business Faculty, Universitas Sebelas Maret, Surakarta, Indonesia [2] Lecturer, Economics and Business Faculty, Universitas Muhammadiyah Yogyakarta, Indonesia [Postal Address:

Jl. Brawijaya, Tamantirto, Kec. Kasihan, Yogyakarta, 55183, Indonesia] Email: agustribasuki@yahoo.com

${ }^{2}$ Lecturer, Economics and Business Faculty, Universitas Sebelas Maret, Surakarta, Indonesia

${ }^{3}$ Lecturer, Economics and Business Faculty, Universitas Sebelas Maret, Surakarta, Indonesia

${ }^{4}$ Lecturer, Economics and Business Faculty, Universitas Sebelas Maret, Surakarta, Indonesia

(c) Copyright: The Author(s)

This is an Open Access article distributed under the terms of the Creative Commons Attribution Non-Commercial License (https://creativecommons.org/licenses/by-nc/4.0/) which permits unrestricted non-commercial use, distribution, and reproduction in any medium, provided the original work is properly cited. unable to fully utilize the enormous wealth of natural resources for the welfare of the people. Strengthening the domestic economic cooperation becomes even more problematic when the state is unable to provide health insurance and decent quality of life for its citizens, failing in reducing inequality among regions and inequality of national income (Nguyen \& Pham, 2020; Olilingo \& Putra, 2020; Sandip et al., 2020; Tariq et al., 2020). These outstanding problems could be solved by reducing reliance on foreign debt and imports in the midst of the great production tools, abundant global corporate capital, and reduced national oil reserves.

Theoretically, from the economics point of view, investment is the purchase of capital or goods that are not consumed, but used for production activities in order to produce products or services in the future. Some literature related to investment and economic growth, such as Barro (1991), argues that economic growth is not significantly associated with public investment stocks. Sylwester (2000) states that increased levels of human capital have no positive relationship, and a direct influence on growth. Nawatmi (2013) explains that investment has a positive influence on economic growth. 
In practical terms, government spending will affect economic activity, not only encouraging the development process, but also adding to the aggregate product. Srithongrung and Kriz (2014) emphasized that public capital expenditure has a positive effect on economic growth in both the short and medium term. Dudzevičiùte (2018) states that government spending has no relationship with economic growth in European Union countries during the 1994-2012 period. Kosor, at al. (2019) concluded that high levels of government spending are a barrier to growth in developed countries

The debate over the relationship between corruption and growth continues in the modern world. Economists, historians, and political experts have been involved in a lengthy debate over whether corruption endangers economic growth. The general view holds that corruption disrupts economic activities by distorting the efficient allocation of resources in the economy. Mauro (1995) argues that corruption can reduce investment, thereby reduces economic growth. Brempong (2002) states that corruption reduces the rate of revenue growth. An increase of one unit of corruption index reduces the GDP growth rate between 0.75 and 0.9 percentage points, and per capita income is between 0.39 and 0.41 percentage points. These rates are relatively significant given the slow economic growth in Africa. Corruption lowers the rate of per capita income growth since it reduces the productivity of existing resources and ultimately reduces investment. Nawatmi (2013) also states that corruption has a negative influence on economic growth. The sincerity from the government in building this area is measured by the existence of a government system known as Regional Autonomy. In support of this, the government passed Law Number 22 of 1999 on Regional Government, which was subsequently revised to Law No.32 of 2004 and Law No. $25 / 1999$ on the financial balance between the central and regional government, which was subsequently changed into Laws Law Number 33 Year 2004.

From the above background, this study analyzes determinants of the growth of selected provinces in Indonesia. This study is expected to document the role of local government expenditures, particularly in the area of education, health, marine and fisheries, agriculture, general allocation funds, population and foreign investment, and opinion of the Supreme Audit Board to the Regional Government Financial Reports in promoting economic growth, creating effectiveness and harmony in regional economic development, as well as the attainment of good governance.

Therefore, the purpose of this study is to uncover the effect of population size, government expenditure on education, government expenditures on health, government expenditures on marine and fisheries, government expenditures on agriculture, general allocation funds, foreign investment and opinion of the Supreme Audit Agency against Local Government Financial Statements on regional economic growth.

\section{Literature Review}

This section discusses the literature on the factors driving economic growth in various regions. Several studies have shown that a number of factors influence economic growth, such as the research conducted by Sylwester (2000) and Gisore (2014), which states that population growth coupled with efforts to improve health, education and welfare in general will drive economic growth. Meanwhile, Bloom, et al (2010) stated that an aging population will tend to reduce labor force participation and the saving rate, thereby increasing concerns about slowing economic growth in the future. Differently, development has a broader meaning compared to economic growth. The increase in production is indeed one of the main characteristics in the development process. In addition, in terms of quantitative aspects, the development process involves changes in the composition of production, changes in the pattern of use of production resources among economic sectors, changes in the pattern of distribution of wealth and income among various economic actors, and changes in the institutional framework in the society as a whole.

The important thing in the development process is an increasing opportunity on productive employment. Economic development should open active participation in productive activities for all members of society who are eligible to participate in the economic process. The productive economic activity contains many positive impacts, including adding real income to the majority of the population. It can increase the purchasing power of consumption both qualitatively and quantitatively. According to Adam Smith, economic development is a process of integration between population growth and technological progress. Todaro and Smith (2009) define development as a multidimensional process involving significant changes in social structure, public attitudes, national institutions as well as the acceleration of economic growth, the reduction of inequality and the abolition of absolute poverty.

The notion of economic development, according to Kuznets, is the ability of a country to provide more types of economic goods to its inhabitants in the long run. This ability covers technological advances, institutional and ideological adjustments. This definition has three components: first, the economic growth of a nation is viewed from the continuous increase of inventories; second, advanced technology determines the degree of growth over various goods on the population; thirdly, the widespread and efficient use 
of technology requires adjustment in the institutional and ideological fields so that the innovations produced by human science can be properly utilized. Economic growth is the process of increasing output in the long run (Mankiw, 2013). This definition includes three aspects: process, output per capita, and long term.

According to the above studies, economic development is defined as a process that causes income per-capita population of a society to increase in the long term. It contains three elements: (1) economic development as a process that continuously changes, denoting an ability for new investments; (2) increasing income per capita; (3) an increase in per-capita income in the long run.

\section{Previous Studies}

Rapid population growth poses severe implications for the welfare of humanity in the world. Its effects could be in the form of supporting or hindering economic development. Fiscal policy is an economic policy pursued by the government in managing state finance (through spending on education, health spending, agricultural expenditures). Monetary policy deals with state revenues originated from tax or non-tax and then allocated in the form of state expenditure as shown in the Revenue Budget. Sylwester (2000), Dada (2013, Brempong (2002), Li and Liang (2010), and Murova and Khan (2017), conclude that government spending on education has a positive influence on economic development. However, studies by Shora et al. (2014) conclude that government spending on education harms economic development. Meanwhile, Olabisi and Oloni (2012), Gisore (2014) and AlShafti (2012) find that government spending on education allocation does not affect economic growth.

All studies on the effect of health budget on economic growth conclude that health budget bolsters economic growth. Thus, increasing of health budget affects to the better quality of public health. Ultimately, the better quality of public health triggers labor productivity and pushes economic growth. In terms of the economic sector, the role of agriculture in economic development is considered a supporting sector. Growth has been defined by the structural transformation of an economy from agricultural activities to the industrial economy. Thus, the role of government is needed, especially in promoting events in agriculture through the provision of agricultural facilities and infrastructure (such as irrigation, fertilizers and seeds). Oyinbo et al. (2013) state that the agricultural budget has no impact on economic growth. Meanwhile, Armas et al. (2012) state that the government budget for the agricultural sector could boost economic growth.

Government expenditures that are used to influence regional economic development (e.g., educational, health, transport and other infrastructure) will result in increased economic activity and encourage economic growth. But there are also some studies, such as Deswantoro et al. (2017) and Dogan and Tang (2006), that conclude that the government budget does not affect economic growth, while Srinivasan (2013) summarizes that the government budget harms economic growth due to the misallocation of the budget. Other studies, such as Deswantoro et al. (2017) and Olabisi and Oloni (2012) argue that foreign investment reduces economic growth through exclusive agreements in production with the government without taking profit back. Ibhagui (2020) concluded that most of the effects of foreign investment on economic growth are inconsistent. FDI increases growth in Sub-Saharan Africa when private sector inflation and credit are below threshold levels while human capital and population growth are above threshold levels.

The relationship between poverty and economic growth can be generated from Okoroafor and Nwaeze (2013). Empirical results show that there is no correlation between poverty and economic growth in Nigeria. This result is caused by the weakness of the government's policies towards human capital development. According to Afzal (2012), poverty has a strong relationship with education and economic growth in the long run.

Regarding the relationship between corruption and economic growth, some studies argue that corruption can only promote economic growth through two mechanisms (Mauro, 1995). First, the corruption practices can speed things up so as to enable economic actors to avoid the delays of its affairs. It can support economic growth if the country's bureaucracy rules are terrible. Secondly, this corruption can encourage government employees to work harder. Those who had not been too eager to complete their routine matters became stimulated to work because of the corrupted money. In contrast, Nawatmi (2013), Brempong (2002), Mo (2001) and Shora et al. (2014) view that corruption would lower economic growth as well as generate inequalities among people's incomes.

\section{Research Methods}

This study specifies gross domestic regional product (GDRP) as a dependent variable with a specific equation:

\section{GDRP $=\mathrm{f}($ EDUC, HEALTH, MARINE, AGRIC, DAU, POVERT, INF, FDI, OPINI)}

where the GDRP represents gross domestic regional product, EDUC represents local government spending on education, HEALTH represents local government spending on health, MARINE represents local government spending on marine and fisheries, AGRIC represents domestic government 
expenditure on agriculture, DAU represents revenue sharing between central and local government, POVERT symbolizes the number of poor people, INF symbolizes the amount of inflation, FDI symbolizes foreign investment, and OPINI symbolizes the assessment of the Supreme Audit Agency against the Local Government Financial Report.

In order to obtain precise results, there are steps by using the standard procedure. The following actions on Panel VECM procedures are as follows: Unit Root Test, Co-integration Test, Panel Vector Error Correction Model (VECM), Impulse Response Function and Variance Decomposition Test. The details of those steps are explained as follows:

\subsection{Panel Unit Root Tests}

Panel unit root tests can be categorized as "first generation" or "second generation." The most critical tests of the first generation unit root tests are the Levin-Lin-Chu test (LLC) and the Im-Pesaran-Shin test (IPS). These tests are extensions of the traditional augmented Dickey-Fuller (ADF) unit root test for univariate time-series modeling under the restrictive assumption of individual cross-sectional independence. Levin, Lin, and Chu (LLC), Breitung, and Hadri tests assume that there is a standard unit root process so that is identical across cross-sections. The first two tests employ a null hypothesis of a unit root, while the Hadri test uses a null of no unit root.

\subsection{Panel Cointegration Analysis}

Panel cointegration tests provide more reliable results in testing cointegration compared to individual tests. The panel cointegration tests are based on unit root testing of residuals from the OLS-wise regression or commonly called as EngleGranger (EG) based cointegration test. The EG test is derived from the basic idea of cointegration models, where two nonstationary time series are cointegrated if there are some stationary linear combination between them. Consequently, once the null hypothesis is cointegrated, residuals from their stationary linear combination are also fixed. Thus, the EG procedure requires two steps: the estimation of static OLS regression to obtain residuals and then to impose some unit root testing to residuals (not necessarily ADF).

The high interest and the availability of panel data have led to an emphasis on extending various statistical tests to panel data. Recent literature focused on analyses of cointegration in a panel setting. E-Views can compute one of the following types of panel cointegration tests according to Pedroni (1999), Kao (1999) and a Fisher-type test using an underlying Johansen methodology (Maddala and Wu 1999).

The Pedroni and Kao tests are by Engle-Granger (1987) two-step (residual-based) cointegration tests. The Fisher test uses a combined Johansen test.
The Engle-Granger (1987) cointegration test is based on an assessment of the residuals of a spurious regression by using I(1) variables. If the variables are cointegrated, then the residuals should be I(0). On the other hand, if the variables are not cointegrated, then the residuals will be I(1). Pedroni (1999) and Kao (1999) extend the Engle-Granger framework to tests the cointegration by involving panel data. The Kao test follows the same basic approach as the Pedroni tests but specifies cross-section using specific intercepts and homogeneous coefficients on the first-stage regressors.

\subsection{Panel VECM}

If all variables have met the stationary in the first derivative and have passed the cointegration test, then we can proceed with the dynamic panel regression vector error correction model (VECM).

\subsection{Impulse Response Function (IRF)}

IRF can explain the response of one variable to a shock from other variables. So, the influence of shock of one variable because of other variables can be explained clearly. The IRF result shows the length of time needed from one variable to respond the others.

\section{Results and Discussion}

\subsection{Unit Root Test}

According to Table 1, we can see the unit root test referring to Levin, Lin, and Chu t*, IPS W-Stat, Fisher-ADF and Fisher-PP. The null hypothesis has the unit root test (not stationary) and the alternative hypothesis is stationary.

According to Table 1 , the results conclude that all variables namely; GDRP, EDUC, HEALTH, AGRIC, MARINE, DAU, FDI, PROVERT, and POP are not stationary at the level because it does not pass all tests (Levin, Lin and Chu, IPS, Fisher-ADF and Fisher-PP) at alpha 5\%. Thus, the unit root test continues at the First Difference Level.

According to Table 1, the results indicate that all variables are stationary at first difference due to the p-value (probability) less than 5\%. Give that all variables are stationary in first difference; therefore the relationship among all variables will be conducted using VECM estimation.

\subsection{Co-Integration Test}

Kao (1999) presented two types of cointegration tests in panel data, the DF and ADF type tests. Calculation result of cointegration using Kao Test for t-Statistic is -3.33 and value of probability 0.000 . The result indicates that all variables can show cointegration in the long-term. In other words, for 
each short-term period, all variables tend to adjust to reach the long-term equilibrium.

\subsection{Panel Vector Error Correction Model Estimation}

Panel VECM shows the short-term and long-term relationships between variables. On a short-term relationship, one variable tends to adapt due to a change of other variables to form the long-term equilibrium. This estimation uses lag two based on lag length criteria.

Meanwhile, in the long-term estimation, all variables in model 1 affect GDRP at $\alpha=5 \%$ except for government budget expenditure in agriculture. In the long run, there is a shift of development from agrarian to industrial sector, so that the role of the industrial sector is increasingly dominant to replace the agriculture sector. The government budget for education (EDUC) harms Gross Domestic Regional Bruto (GDRP). An increase of 1 percent on the government budget for education will decrease Gross Domestic Regional Bruto for around 0.204736 percent. Additional government budget for education is mostly used for the improvement of educational infrastructure facilities not yet on improving the quality of the graduates. The role of the private sector in Indonesia is dominant than the government.

Table 1: Stationary Test for Level Data and first Difference

\begin{tabular}{|c|c|c|c|c|c|c|c|c|}
\hline \multirow{2}{*}{ Variable } & \multicolumn{2}{|c|}{ Levin, Lin \& Chu $\mathrm{t}^{*}$} & \multicolumn{2}{|c|}{$\begin{array}{c}\text { Im, Pesaran and Shin } \\
\text { W-stat }\end{array}$} & \multicolumn{2}{|c|}{$\begin{array}{c}\text { ADF - Fisher Chi- } \\
\text { square }\end{array}$} & \multicolumn{2}{|c|}{ PP - Fisher Chi-square } \\
\hline & Level & $1^{\text {st }}$ Difference & Level & $1^{\text {st }}$ Difference & Level & $1^{\text {st }}$ Difference & Level & $1^{\text {st }}$ Difference \\
\hline GDRP & 1.191 & $-14.049^{* * *}$ & 3.841 & $-4.650^{* * *}$ & 6.312 & $72.866^{* * *}$ & 9.129 & $100.912^{* * *}$ \\
\hline EDUC & $-3.801^{* \star *}$ & $-22.425^{\star \star \star}$ & 0.069 & $-7.585^{\star * \star}$ & 38.825 & $95.474^{* * *}$ & $52.822^{* *}$ & $106.563^{\star \star \star}$ \\
\hline HEALTH & -0.110 & $-29.393^{* * *}$ & 3.060 & $-7.125^{\star * *}$ & 10.162 & $84.033^{* * *}$ & 8.781 & $92.119^{* * *}$ \\
\hline AGRIC & -0.432 & $-12.892^{\star \star *}$ & 3.479 & $-4.632^{* * *}$ & 5.860 & $72.337^{* * *}$ & 4.263 & $96.656^{* * *}$ \\
\hline MARINE & -1.294 & $-16.451^{* * *}$ & 2.256 & $-5.236^{* * *}$ & $14 \mathrm{~s} .080$ & $75.851^{* * *}$ & 15.413 & $88.938^{* * *}$ \\
\hline DAU & -1.524 & $-25.770^{* \star *}$ & 2.984 & $-8.118^{* * *}$ & 8.653 & $99.912^{* * *}$ & 11.079 & $107.133^{* \star *}$ \\
\hline FDI & $-3.137^{* * *}$ & $-25.799^{* * *}$ & 0.487 & $-7.236^{* * *}$ & 33.180 & $88.273^{* * *}$ & 42.602 & $101.371^{* \star *}$ \\
\hline POVERT & $-3.810^{* * *}$ & $-11.245^{\star \star \star}$ & -0.067 & $-3.607^{* * *}$ & 35.911 & $63.557^{* * *}$ & $51.046^{* * *}$ & $80.109^{* * *}$ \\
\hline POP & -1.338 & $-10.013^{* * *}$ & 2.045 & $-3.121^{* \star *}$ & 19.657 & $57.235^{\star \star \star}$ & 31.450 & $76.138^{* * *}$ \\
\hline
\end{tabular}

Source: data processed

${ }^{* * *}$ sign at a $1 \%{ }^{* *}$ sign at $\alpha 5 \%{ }^{*}$ sign at a $10 \%$

Table 2: Regression Analysis-Long Term Relationships

\begin{tabular}{|l|c|c|c|}
\hline \multirow{2}{*}{ CointEq } & Model 1 & Model 2 & Model 3 \\
\cline { 2 - 4 } & CointEq1 & CointEq1 & CointEq1 \\
\hline LEDUC(-1) & $-0.901^{* * *}$ & $1.122^{* * *}$ & $-0.205^{* * *}$ \\
\hline LHEALTH(-1) & $0.540^{* * *}$ & $-1.228^{* * *}$ & -0.174 \\
\hline LAGRIC(-1) & 0.205 & 0.583 & $1.208^{* * *}$ \\
\hline LMARINE(-1) & $0.391^{* * *}$ & $-1.558^{* * *}$ & $-1.108^{* * *}$ \\
\hline LDAU(-1) & $0.169^{* *}$ & $2.035^{* * *}$ & $0.773^{* * *}$ \\
\hline LFDI(-1) & $-0.355^{* * *}$ & 0.128 & $-0.156^{* * *}$ \\
\hline LPOVERT(-1) & $-1.064^{* * *}$ & $1.412^{* * *}$ & $0.364^{* * *}$ \\
\hline LPOP(-1) & & $-3.065^{* * *}$ & $-1.535^{* * *}$ \\
\hline OPINI(-1) & & & $-0.436^{* * *}$ \\
\hline
\end{tabular}

Source: data processed

${ }^{* * *}$ sign at $\alpha 1 \%{ }^{* *}$ sign at $\alpha 5 \%{ }^{*}$ sign at $\alpha 10 \%$ 
In addition, the government budget for health (HEALTH) has a positive impact on Gross Domestic Regional Bruto (GDRP). An increase of 1 percent on the government budget for hygiene will increase Gross Domestic Regional Bruto for 0.540412 percent due to in the long term, and people have understood the importance of health. The government budget for health increases especially for the inland areas. Increasing health budgets in rural areas will encourage economic growth by improving public health.

The government budget for agriculture (AGRIC) has no impact on Gross Domestic Regional Bruto (GDRP), but in model 3 the government budget for agriculture has a positive effect on economic growth. An increase of 1 percent on the government budget for agriculture will increase Gross Domestic Regional Bruto for around 1.208719 percent.

The government budget for Marine and fisheries (MARINE) has a positive impact on Gross Domestic Regional Bruto (GDRP), but in models2 and 3, the government budget for Marine and fisheries has a negative effect on economic growth. An increase of 1 percent on the government budget for Marine and fisheries will increase Gross Domestic Regional Bruto for 0.390558 percent in model 1. In the long run, the government should allocate a larger budget for marine and fishing due to the rapid of territorial waters accompanied by the number of fish thefts by other countries

The central government budget fund to local governments (DAU) has a positive impact on Gross Domestic Regional Bruto (GDRP). An increase of 1 percent on central government budget funds to local governments will increase Gross Domestic Regional Bruto for around 0.773379 percent. It shows that the policy of the government, especially the central to the regional division of power is very successful in encouraging regional economic growth.

Direct investment of foreign capital (FDI) has a negative impact on Gross Domestic Regional Bruto (GDRP). An increase of 1 percent on foreign direct investment will decrease Gross Domestic Regional Bruto for around 0.156160 percent. The relationship between foreign investment and economic growth shows a negative correlation. So far, foreign investment in Indonesia has been exploring natural resources and focusing on regions that only relies on natural resources. Hence, they have low average economic growth. Thus, the government must make a policy to raise the added value of natural products so that the investment role can be optimally used. This finding is supported by Deswantoro et al. (2017) and Olabisi and Oloni (2012) that foreign capital investment reduces economic growth through exclusive agreements in production with the government. Criticisms of foreign investment have mainly been undertaken due to the uneven impacts of development outcomes in Indonesia and many cases the activities of foreign capital firms that only reinforce the dualistic economic structure and exacerbate the distribution of income. They will divert resources from use to produce food to use to deliver sophisticated goods that mostly satisfy only certain groups and tend to exacerbate the imbalance of economic opportunities between rural and urban areas with most operating in urban areas and accelerate the flow of urbanization from village to city. Foreign investment companies tend to produce unsuitable goods (only consumed by certain groups), thus encouraging the luxury consumption pattern through advertising and the resulting goods tend to use capital-intensive technology. So, domestic resources tend to be allocated to socially unprofitable projects.

The total poor population (POVERT) has a negative impact on Gross Domestic Regional Bruto (GDRP). An increase of 1 percent of total poor population will decrease Gross Domestic Regional Bruto by around 1.06 percent. But in model 3 total poor population (POVERT) has a positive impact on Gross Domestic Regional Bruto (GDRP). An increase of 1 percent of the total poor population will decrease Gross Domestic Regional Bruto by 1.063509 percent.

The total population (POP) has a negative impact on Gross Domestic Regional Bruto (GDRP). An increase of 1 percent of the total population will decrease Gross Domestic Regional Bruto by 1.53 percent. While the opinion of the financial auditing agency to the local government financial statements has a negative effect, meaning that a better assessment of view will reduce economic growth. It occurs because opinion judgments are based solely on the procedures of using local budgets, whether they are in accordance with the rules applied or not, but do not see the results of their work. In addition, the assessment has not been based on the performance of regional funds.

The opinion of the Supreme Audit Agency against Local Government Financial Statements has a negative relationship to regional economic growth. So far, local governments have not optimized the performance-based budget, which is implemented only limited to budget absorption, and this has not affected the outcome of each program. This finding is supported by Mauro (1995). The existence of this corruption can encourage government employees to work harder. Those who had not been too eager to complete their routine matters became motivated to work hard because of the incentives of his service money. To avoid corruption, it is necessary to optimize the institution of the Financial Eradication Commission.

The short-term (Table 3) relationship indicates that the government budget for education (EDUC) is at lag 1 and positively influences GDRB at $\alpha=5 \%$ for about 0.026 . It means when there is an increase of 1 percent in the government budget for education on the previous year, it will increase the gross domestic regional product by around 0.025538 percent. The government budget for health (HEALTH) is significant at lag 2, which has a positive influence on GDRB for about 0.037818 percent. It explains that an increasing 1 percent of the government budget for health in the previous two years will increase gross domestic regional product by around 0.038 percent. 
Table 3: Regression Analysis- Short Term

\begin{tabular}{|l|c|c|c|}
\hline \multirow{2}{*}{ Error Correction: } & Model 1 & Model 2 & Model 3 \\
\cline { 2 - 4 } & DLGDRP & DLGDRP & $0.023^{* * *}$ \\
\hline CointEq1 & $-0.019^{* * *}$ & $0.011^{* * *}$ & $-0.457^{* * *}$ \\
\hline DLGDRP(-1) & $-0.301^{* * *}$ & $-0.458^{* * *}$ & $0.454^{* * *}$ \\
\hline DLGDRP(-2) & $0.584^{* * *}$ & $0.479^{* * *}$ & $0.0258^{* * *}$ \\
\hline DLEDUC(-1) & -0.003 & $0.012^{*}$ & 0.003 \\
\hline DLHEALTH(-1) & 0.052 & $0.031^{* * *}$ & $0.038^{* * *}$ \\
\hline DLHEALTH(-2) & $0.039^{* *}$ & 0.041 & $0.032^{* * *}$ \\
\hline DLAGRIC(-1) & 0.015 & $0.044^{* * *}$ & -0.005 \\
\hline DLMARINE(-1) & $0.041^{* * *}$ & 0.000 & $0.015^{*}$ \\
\hline DLMARINE(-2) & $0.035^{* * *}$ & $0.0180^{*}$ & $-0.031^{* * *}$ \\
\hline DLDAU(-2) & -0.016 & $-0.025^{* * *}$ & $0.006^{* * *}$ \\
\hline DLFDI(-1) & -0.003 & 0.003 & 0.000 \\
\hline DLFDI(-2) & $-0.007^{*}$ & -0.002 & -0.045 \\
\hline DLPOVERT(-1) & $-0.173^{* * *}$ & -0.040 & $-0.459^{* * *}$ \\
\hline DLPOP(-2) & & $-0.426^{* * *}$ & $0.056^{* * *}$ \\
\hline C & $0.021346^{*}$ & $0.050^{* * *}$ & 0.837 \\
\hline R-squared & 0.656670 & 0.847 & $7.861^{* * *}$ \\
\hline F-statistic & 4.050324 & 9.732 & \\
\hline
\end{tabular}

Source: data processed

${ }^{* * *}$ sig at $\alpha 1 \% \quad * *$ sig at $\alpha 5 \% \quad * \operatorname{sig}$ at $\alpha 10 \%$

The government budget for agriculture (AGRIC) is significant at lag 2, which has is positively influencing GDRB for about 0.032 percent. It explains that an increasing 1 percent of the government budget for agriculture in the previous two years will increase gross domestic regional product by 0.032 percent.

The government budget for marine and fisheries (MARINE) is significant at lag 2, which has a positive influence on GDRB for about 0.015366 percent. It explains that an increasing 1 percent of the government budget for marine and fisheries on the previous two years will increase gross domestic regional product by 0.015366 percent.

The central government funding funds to local governments (DAU) are significant at lag 2, which has a negative influence on GDRB for about 0.016 percent. It explains that an increasing 1 percent of central government funding funds to local governments in the previous two years will decrease gross domestic regional product by 0.016 percent.

Foreign Direct Investment (FDI) is significant at lag 1, which has a positive influence on GDRB for about 0.015 percent. It explains that an increasing 1 percent of foreign direct investment (FDI) in the previous years will increase gross domestic regional product by 0.015 percent.

The last significant variable is the total population (POP) at lag 2, which explains an increase of total population (POP) in the previous two years will decrease gross domestic regional product by 0.459963 percent.

\subsection{Impulse Response Function (IRF)}

This test describes the response from a particular variable due to the shock from other variables. Thus, the length of afterward shock effect until the effect is gone or return to the balance point. This test shows how long the time is needed from one variable to respond to the shock from other variables.

In Figure 1.a, LEDUG starts to respond to the shock in the first period. LEDUC tends to respond to the gross domestic regional product in a fluctuating manner. Entering the second period until the eighth, the changes are volatile. And after the eighth period, the differences tend to be stable. The graph explains that the increase in the government budget for education (EDUC) will increase gross domestic regional product. 


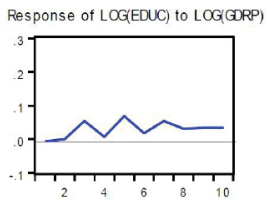

a

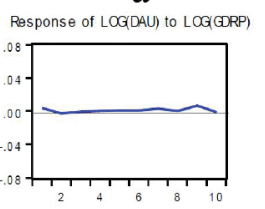

e

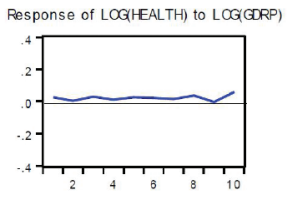

$\mathrm{b}$

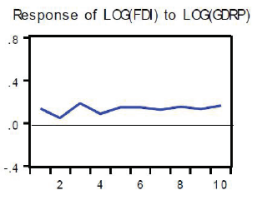

$\mathrm{f}$

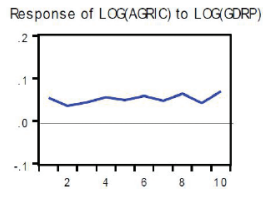

C

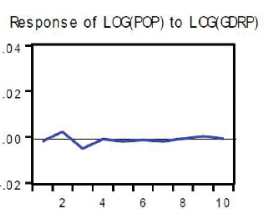

g

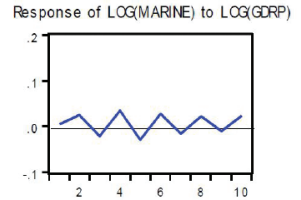

d

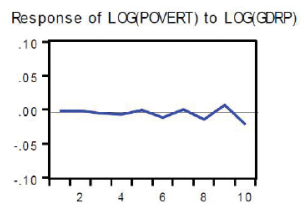

$\mathrm{h}$

Figure 1: Response of exogenous variables to Log (GDRP)

In Figure 1.b, LHEALTH starts to respond to the shock in the first period. LHEALTH tends to respond to gross domestic regional products in a stable manner. Entering the eighth period until the ninth tends to fall, and again increased in the ninth period. The graph explains that the increase in the government budget for health (HEALTH) will increase slowly to gross domestic regional products.

In Figure 1.c, LAGRIC starts to response the shock at the first period. LAGRIC tends to respond to gross domestic regional product stably. Entering the eighth period until the ninth tends to fall, and again increased in the ninth period. The graph explains that the increase in the government budget for health (HEALTH) will increase slowly to gross domestic regional product.

In Figure 1.d, LMARINE starts to respond to the shock in the first period. LMARINE tends to respond to gross domestic regional product positively. The second to third period increases, the third to fourth period decreases, and the next period increases. And after the ninth period increases. The graph explains that the increase in the government budget for marine (MARINE) will increase gross domestic regional product.

In Figure 1.e, LDAU starts to respond to the shock in the first period. LDAU tends to respond to gross domestic regional product positively. The first period until the ninth period increased slowly, and after the ninth period, there was a decline. The graph explains that the increase in central government funding funds to local governments (DAU) will increase slowly to the gross domestic regional product.

In Figure 1.f, LFDI starts to respond to the shock in the first period. LFDI tends to respond to gross domestic regional product positively. Entering the first to the second period of decline, and entering the second period until the tenth period has increased. The graph explains that the increase in foreign direct investment (FDI) will increase slowly to gross domestic regional product.
In Figure 1.g, LPOP starts to respond to the shock in the first period. LPOP tends to respond to gross domestic regional product slowly positively. Entering the first period until the second increase, and entered the second period until the third period decreased, after the third to the tenth period there was a prolonged increase. The graph explains that the increase in total population (POP) will increase slowly to the gross domestic regional product.

In Figure 1.h, LPOVERT starts to respond to the shock at entering the fifth period. LPOVERT tends to respond to gross domestic regional product fluctuate. Entering the first period until the fifth influence of the poor on the GDRP is very stable, entering the sixth period varies, and after the ninth period decreases. The graph explains that the increase in the Total poor population (POVERT) will decrease slowly to the gross domestic regional product.

\section{Conclusion and Policy Implications}

From the analysis, the study concludes as follows:

In the long run, all variables affect economic growth except for government spending on agriculture. In line with the literature that economic development means a process of change from the agricultural sector to the industrial and service sectors. It can be interpreted in the long run by looking at the role of agriculture that will be reduced and replaced by the role of industry and services.

In the short term, government budget for education is significant at lag 1, government budget for agriculture at lag 2, government budget for marine and fisheries at lag 2, central government funding funds to local governments at lag 2 , foreign direct investment at lag 1 , and total population at lag 2, which explain an increase of gross domestic regional product. Interestingly, the role of the assessment of financial institutions of the Republic of Indonesia against the Financial Report of the Local Government 
does not influence economic growth. Financial audits are conducted in order to provide an opinion on the fairness of financial information presented in the financial statements. Performance audit aims to assess the economic aspects, efficiency, and effectiveness, but do not see the outcomes. BPK assessment is very reasonable to be conducted, but macroeconomic performance is not achieved as expected. The government should have started implementing performance-based budgets where budgeting is structured with output orientation. By building a budgeting system that can integrate performance planning with an annual budget, there will be a link between available funds and the expected outcomes.

From the results of the study, the central and local governments need to implement the following policies:

The government needs to re-evaluate the basic education in terms of curriculum, teaching methods, and educational evaluation. So, it is not only the pursuit of quantity, but also maintaining the quality of basic education.

Foreign investment companies tend to produce unsuitable goods (only consumed by certain groups), thus encouraging the luxury consumption pattern through advertising and the use of capital-intensive technology. Hence, domestic resources tend to be allocated to socially-unprofitable projects. Central and local governments should be selective in granting permits to foreign companies, particularly those who are willing to invest in Indonesia. Especially in the case of the use of waste, labor and supporting development that supports environmental sustainability.

The government needs to simplify procedures and optimize the role of the KPK, as well as the inherent supervisory agencies related to the use of budgets for public purposes.

\section{References}

Afzal, M. (2012). Relationship among Education, Poverty and Economic Growth in Pakistan: An Econometric Analysis. Journal of Elementary Education, 22(1) 23-45

Armas, E. B., Osorio, C. G., Moreno-Dodson, B., \& Abriningrum, D. E. (2012). Agriculture Public Spending and Growth in Indonesia. Washington, DC: The World Bank. doi:10.1596/1813-9450-5977

Al-Shatti, A. S. (2014). The Impact of Public Expenditures on Economic Growth in Jordan. International Journal of Economics and Finance, 6(10), 157-167.DOI:10.5539/ijef.v6n10p157.

Barro, R. J. (1991). Economic Growth in a Cross Section of Countries. The Quarterly Journal of Economics, 106(2), 407-443.

Bloom, D. E., Canning, D., \& Fink, G. (2010). Implications of Population Ageing for Economic Growth. Oxford Review of Economic Policy, 26(4), 583-612. doi.org/10.1093/oxrep/ grq038
Brempong, K. G. (2002). Corruption, Economic Growth and Income Inequality in Africa. Econ. Gov. 3, 183-209. DOI: $10.1007 / \mathrm{s} 101010200045$.

Dada, M. A. (2013). Composition Effects of Government Expenditure on Private Consumption and Output Growth in Nigeria: A Single-Equation Error Correction Modelling. Romanian Journal of Fiscal Policy, 4(2), 18-34.

Deswantoro, D. B., Ismail, A., \& Hendarmin, H. (2017). The Influence of Regional Expenditure Based on Economic Classification on Economic Growth and Community Welfare in Regency / City of West Kalimantan Province in 2010-2015. Journal of Business Economics and Entrepreneurship. 6(3), $187-210$

Dogan, E., \& Tang, T. C. (2006). Government Expenditure and National Income: Causality Tests for Five South East Asian Countries. International Business \& Economics Research Journal, 5(10). DOI https://doi.org/10.19030/iber.v5i10.3516

Dudzevičiūtè, G., Šimelytè, A., \& Liučvaitienè, A. (2018). Government Expenditure and Economic Growth in The European Union Countries. International Journal of Social Economics. doi: 10.1108/IJSE-12-2016-0365.

Engle, R. F., \& Granger, C. W. J. (1987). Co-integration and Error Correction: Representation, Estimation, and Testing. Econometrica: Journal of the Econometric Society, 55, 251-276.

Gisore, N. (2014). Effect of Government Expenditure on Economic Growth in East Africa: A Disaggregate Model, European Journal of Business and Social Science, 3(8), 289-304.

Ibhagui, O. (2020). How Does Foreign Direct Investment Affect Growth in Sub-Saharan Africa? New Evidence from Threshold Analysis. Journal of Economic Studies. https://doi.org/10.1108/ JES-06-2018-0198

Kao, C., Chiang, M. H., \& Chen, B. (1999). International R\&D Spillovers: An Application of Estimation and Inference in Panel Cointegration. Oxford Bulletin of Economics and statistics, 61(S1), 691-709.

Kosor, M. M., Perovic, L. M., \& Golem, S. (2019). Efficiency of Public Spending on Higher Education: A Data Envelopment Analysis for EU-28. Problems of Education in the 21st Century, 77(3), 396. DOI: $10.33225 / \mathrm{pec} / 19.77 .396$.

Li, H., \& Liang, H. (2010). Health, Education, and Economic Growth in East Asia. Journal of Chinese Economic and Foreign Trade Studies. doi: 10.1108/17544401011052267

Maddala, G. S., \& Wu, S. (1999). A Comparative Study of Unit Root Tests With Panel Data and A New Simple Test. Oxford Bulletin of Economics and Statistics, 61(S1), 631-652.

Mauro, P. (1995). Corruption and Growth, The Quarterly Journal of Economics, 110(3), 681-712.

Murova, O., \& Khan, A. (2017). Public Investments, Productivity and Economic Growth: A Cross-State Study of Selected Public Expenditures in The United States. International Journal of Productivity and Performance Management, 66, 251-265. http://dx.doi.org/10.1108/IJPPM-12-2015-0190 
Mo, P. H. (2001). Corruption and Economic Growth. Journal of Comparative Economics, 29(1),66-79. doi:10.1006/jcec.2000.1703

Nawatmi, S. (2013). Corruption and Economic Growth-Empirical Studies 33 Provinces in Indonesia, Journal of Accounting Dynamics, Finance and Banking, 2(1), 66-81.

Nguyen, L. P., \& Pham, V. H. T. (2020). Trade of ICT Products, Government, and Economic Growth: Evidence from East AsiaPacific Region. Journal of Asian Finance, Economics and Business, 7(8), 175-183. https://doi.org/10.13106/jafeb.2020. vol7.no8.175

Olabisi, A. S., \& Oloni, E. F. (2012). Composition of Public Expenditure and Economic Growth in Nigeria. Journal of Emerging Trends in Economics and Management Sciences, 3(4), 403-407.

Olilingo, F. Z., \& Putra, A. H. P. K. (2020). How Indonesia Economics Works: Correlation Analysis of Macroeconomics in 2010 - 2019. Journal of Asian Finance, Economics and Business, 7(8), 117130. https://doi.org/10.13106/jafeb.2020.vol7.no8.117

Oyinbo, O., Zakari, A., \& Rekwot, G. Z. (2013). Agricultural Budgetary Allocation and Economic Growth in Nigeria: Implications for Agricultural Transformation in Nigeria. Consilience, (10), 16-27.

Sandip, S., Krishna Murthy, I., \& Asmita, C. (2020). Sectoral Contribution to Economic Development in India: A Time-Series
Co-Integration Analysis. Journal of Asian Finance, Economics and Business, 7(9), 191-200. https://doi.org/10.13106/ jafeb.2020.vol7.no9.191

Srinivasan, P. (2013). Causality Between Public Expenditure and Economic Growth: the India Case. International Journal of Economics and Management, 7(2), 335-347.

Srithongrung, A., \& Kriz, K. A. (2014). The Impact of Subnational Fiscal Policies on Economic Growth: A Dynamic Analysis Approach. Journal of Policy Analysis and Management, 33(4), 912-928. Doi: 10.1002/pam.21784

Pedroni, P. (1999). Critical Values for Cointegration Tests in Heterogeneous Panels with Multiple Regressors. Oxford Bulletin of Economics and Statistics, 61(S1), 653-670.

Sylwester, K. (2000). Income Inequality, Education Expenditures and Growth. Journal of Development Economics, 63(2), 379398. DOI: 10.1016/S0304-3878(00)00113-9

Tariq, R., Khan, M. A., \& Rahman, A. (2020). How Does Financial Development Impact Economic Growth in Pakistan? New Evidence from Threshold Model. Journal of Asian Finance, Economics and Business, 7(8), 161-173. https://doi. org/10.13106/jafeb.2020.vol7.no8.161

Okoroafor, M. O., \& Nwaeze, C. (2013). Poverty and Economic Growth in Nigeria 1990-2011. The Macrotheme Review, 2(6), 105-115. 